\title{
The latest Ediacaran Wormworld fauna: Setting the ecological stage for the Cambrian Explosion
}

article version: published manuscript

Schiffbauer, James D.

Huntley, John Warren

O’Neil, Gretchen R.

Darroch, Simon F.

Laflamme, Marc.

Cai, Yaoping

Schiffbauer, J. D., Huntley, J. W., O’Neil, G. R., Darroch, S. A., Laflamme, M., \& Cai, Y. (2016). The latest Ediacaran Wormworld fauna: Setting the ecological stage for the Cambrian Explosion. GSA Today, 26(11). doi: 10.1130/GSATG265A.1

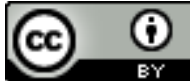

\section{HOW TO CITE TSPACE ITEMS}

Always cite the published version, so the author(s) will receive recognition through services that track citation counts, e.g. Scopus. If you need to cite the page number of the TSpace version (original manuscript or accepted manuscript) because you cannot access the published version, then cite the TSpace version in addition to the published version using the permanent URI (handle) found on the record page. 


\section{The Latest Ediacaran Wormworld Fauna: Setting the Ecological Stage for the Cambrian Explosion}

\begin{abstract}
James D. Schiffbauer*, John Warren Huntley, Gretchen R. O'Neil**, Dept. of Geological Sciences, University of Missouri, Columbia, Missouri 65211, USA; Simon A.F. Darroch, Dept. of Earth and Environmental Sciences, Vanderbilt University, Nashville, Tennessee 37235, USA; Marc Laflamme, Dept. of Chemical and Physical Sciences, University of Toronto Mississauga, Mississauga, Ontario L5L 1C6, Canada; Yaoping Cai, State Key Laboratory of Continental Dynamics and Dept. of Geology, Northwest University, Xi'an, 710069, China
\end{abstract}

\section{ABSTRACT}

As signposted by the fossil record, the early Cambrian period chronicles the appearance and evolutionary diversification of most animal phyla in a geologically rapid event, traditionally termed the Cambrian Explosion. The uniqueness of this event pleads for a cause, and over the years, numerous biotic and abiotic factors have been offered as possible triggers. Many such explanations, however, either fail to correspond in time or do not provide a functional mechanism to explain the evolutionary pattern of animal diversification. We support the notion that a series of requisite biotic and abiotic events ushered in the Cambrian Explosion, wherein each event was necessary for the implementation of later events but did not guarantee their occurrence. The evolution of the terminal Ediacaran vermiform fauna was integral in the construction of the Eltonian pyramid, fostered an escalation of ecosystem engineering and macropredation, and represented a turning point in benthic ecosystems from those governed primarily by competition for space and resources to those also shaped by these novel pressures.

\section{INTRODUCTION}

Relative to its mass, the biosphere disproportionately impacts other components of the Earth system. It oxygenates the oceans and atmosphere, regulates global geochemical cycles, and influences rates and patterns of global change. Life leaves distinctive signals in the rock record, and few are more striking than those at the onset of the Phanerozoic — one of the most intensely studied intervals in the geologic record. The Cambrian Explosion-as famously revealed in the Burgess and Maotianshan shalesrepresents the geologically abrupt ( $\sim 25$ million years [m.y.]) appearance and diversification of nearly all major metazoan phyla. This proliferation of the roots of the animal phylogenetic tree and rapid expansion of morphological complexity was one of the more significant macroevolutionary events in life history and coincided with a variety of global-scale biotic and abiotic changes (Fig. 1; Briggs et al., 1992; Erwin, 2007) — some of which were brought about by metazoan activities, while others elicited a response by metazoans.

Molecular divergence time estimates (e.g., Erwin et al., 2011; Peterson et al., 2008) suggest that the last common ancestor of all animals evolved in the Cryogenian (ca. $800 \mathrm{Ma}$; although see dos Reis et al., 2015, for caveats). The earliest interpreted stem-group animals, however, are the ca. $600 \mathrm{Ma}$ Doushantuo embryo-like microfossils (Chen et al., 2014a; Yin et al., 2016), leaving a 200 -m.y. interlude between the fossil and molecular records. This hiatus between the estimated origin of Metazoa and their first appearance in the fossil record highlights the growing realization that the earliest stages of animal diversification were neither truly Cambrian nor explosive-with the phylogenetic origin of animals temporally removed from their morphological and ecological diversification by a long fuse (e.g., Conway Morris, 2000; Xiao, 2014). In this case, the significant lag between the establishment of the developmental toolkits necessary for the origin of novelty and their later implementation and ecological success can perhaps be attributed to the uniqueness of newly developing animal ecosystems. Between the ignition of the fuse and the subsequent evolutionary boom, three major eco-environmental feedbacks (see Erwin et al., 2011) arose that helped to pave the way for the Cambrian Explosion: (1) linkages between the pelagic and benthic ecosystems; (2) expansion of ecosystem engineering; and (3) metazoan macropredation. These feedbacks are explored herein in the context of the terminal Ediacaran fossil record of vermiform organisms. This "wormworld" biotacomprised of various tubicolous body fossils (Figs. 2A-2C), such as the cloudinids, and increasingly complex vermiform ichnofossils (Figs. 2D-2F) — critically occupied a fundamental phase shift from competition- to predation-governed marine benthic ecosystems.

\section{BUILDING THE ELTONIAN PYRAMID \\ Competition and Nutrient Acquisition}

The classic Ediacara biota were unheralded in life history, emerging ca. $578 \mathrm{Ma}$ with new and complex multicellular morphologies unlike anything seen before (Narbonne, 2005). While some of these sessile and epibenthic curiosities have been posited as stem-group animals (e.g., Budd and Jensen, 2015), for the most part they lack convincing metazoan synapomorphies, leaving their positioning within the tree of life unresolved. These fossils, however, do provide clues as to how Ediacaran ecosystems

GSA Today, v. 26, no. 11, doi: 10.1130/GSATG265A.1.

*Email: schiffbauerj@missouri.edu

${ }^{* *}$ Now at North Dakota State University, Dept. of Geosciences, Stevens Hall, 1340 Bolley Drive \#201, Fargo, North Dakota 58102, USA. 


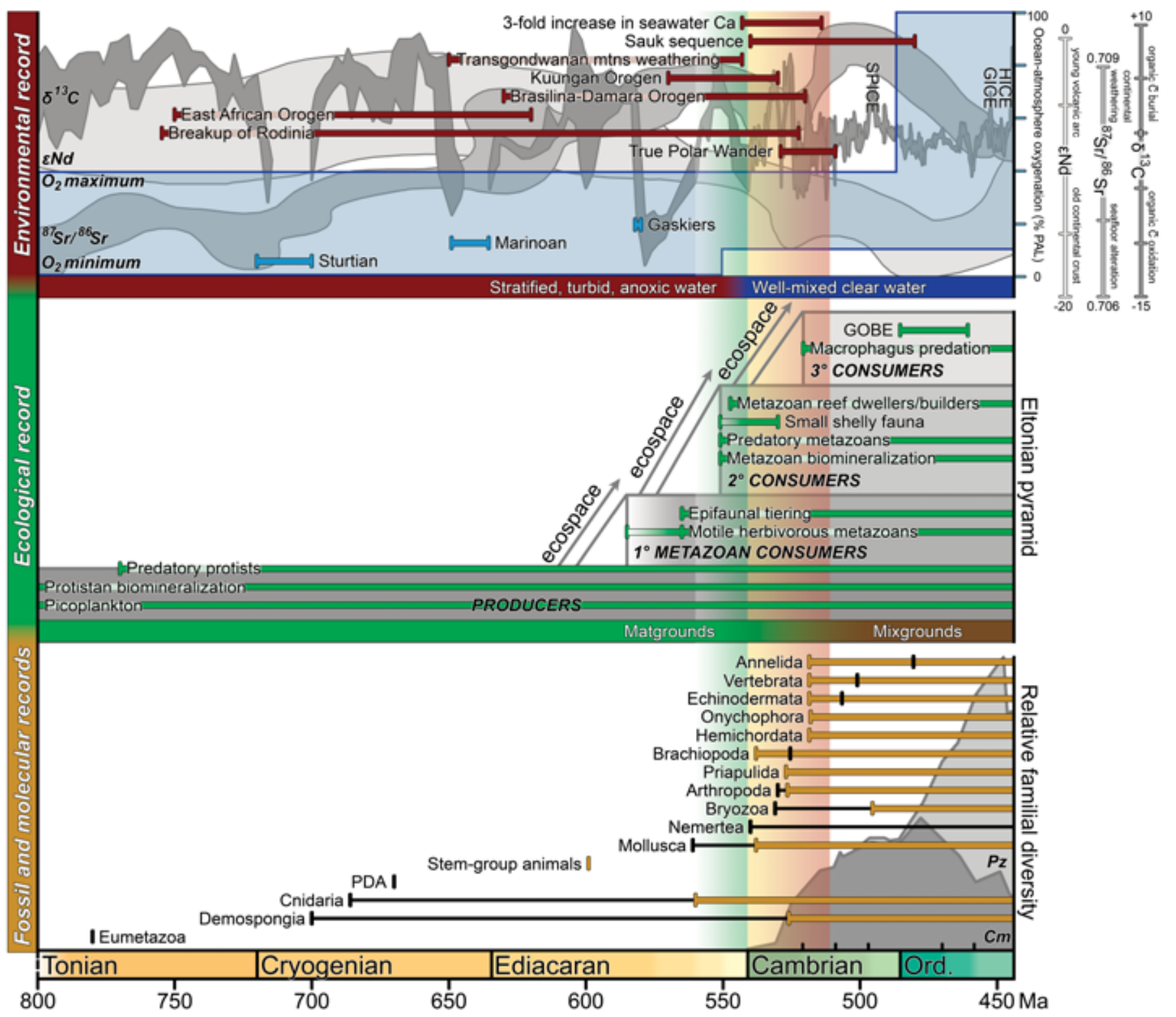

Figure 1. Compilation of temporally associated significant events and records during the Neoproterozoic-Paleozoic transition. From bottom to top: (i) fossil (yellow bars-first appearance) and molecular (black bars—reported divergence estimates; Erwin et al., 2011) records superimposed on the Cambrian and Paleozoic faunas of Sepkoski (1981); (ii) ecological record (green bars) indicating first appearances of important behaviors/events overlain on gray rectangles comprising the Eltonian pyramid and diagrammed after megatrajectories of Knoll and Bambach (2000); and (iii) environmental record of major Earth system events (light blue bars—Snowball Earth glaciations; maroon bars—orogenies and other events), with ocean-atmosphere oxygenation data (blue-gray, Sperling et al., 2015), $\varepsilon N d$ (light gray, Keto and Jacobson, 1988) and ${ }^{87} \mathrm{Sr} /{ }^{86} \mathrm{Sr}$ estimates (mid-gray, Maloof et al., 2010), and the $\delta^{13} \mathrm{C}$ record (dark gray, Saltzman and Thomas, 2012). The Cambrian Explosion is indicated by the yellow-orange column, and the temporal expanse of the wormworld fauna by the green column. GICE—Guttenberg Carbon Isotope Excursion; GOBE—Great Ordovician Biodiversification Event; HICE—Hirnantian Carbon Isotope Excursion; PDA — protostome-deuterostome ancestor; SPICE—Steptoean Positive Carbon Isotope Excursion.

functioned. For instance, vertical tiering in fossil communities at Mistaken Point, Canada, highlights the importance of competitive nutrient acquisition from the seawater (Clapham and Narbonne, 2002; Ghisalberti et al., 2014). Filter feeding was likely well established, as evidenced by putative Cryogenian sponges (Maloof et al., 2010, though see Antcliffe et al., 2014) and less contested Ediacaran sponges (Yin et al., 2015) — which, along with the evolution of zooplankton (Butterfield, 1997), served to deliver waste organics to the substrate, providing a direct link between pelagic and benthic ecosystems. Nonetheless, while some Ediacaran taxa may have gained nutrients through suspension feeding (Rahman et al., 2015), osmotrophy (Laflamme et al., 2009), or saprotrophy (the latter two of which are rare to absent in extant Metazoa; Sperling and Vinther, 2010), the feeding strategies of most Ediacaran taxa remain indeterminate due to the abundance of non-analogue body plans. It is likely, though, that 


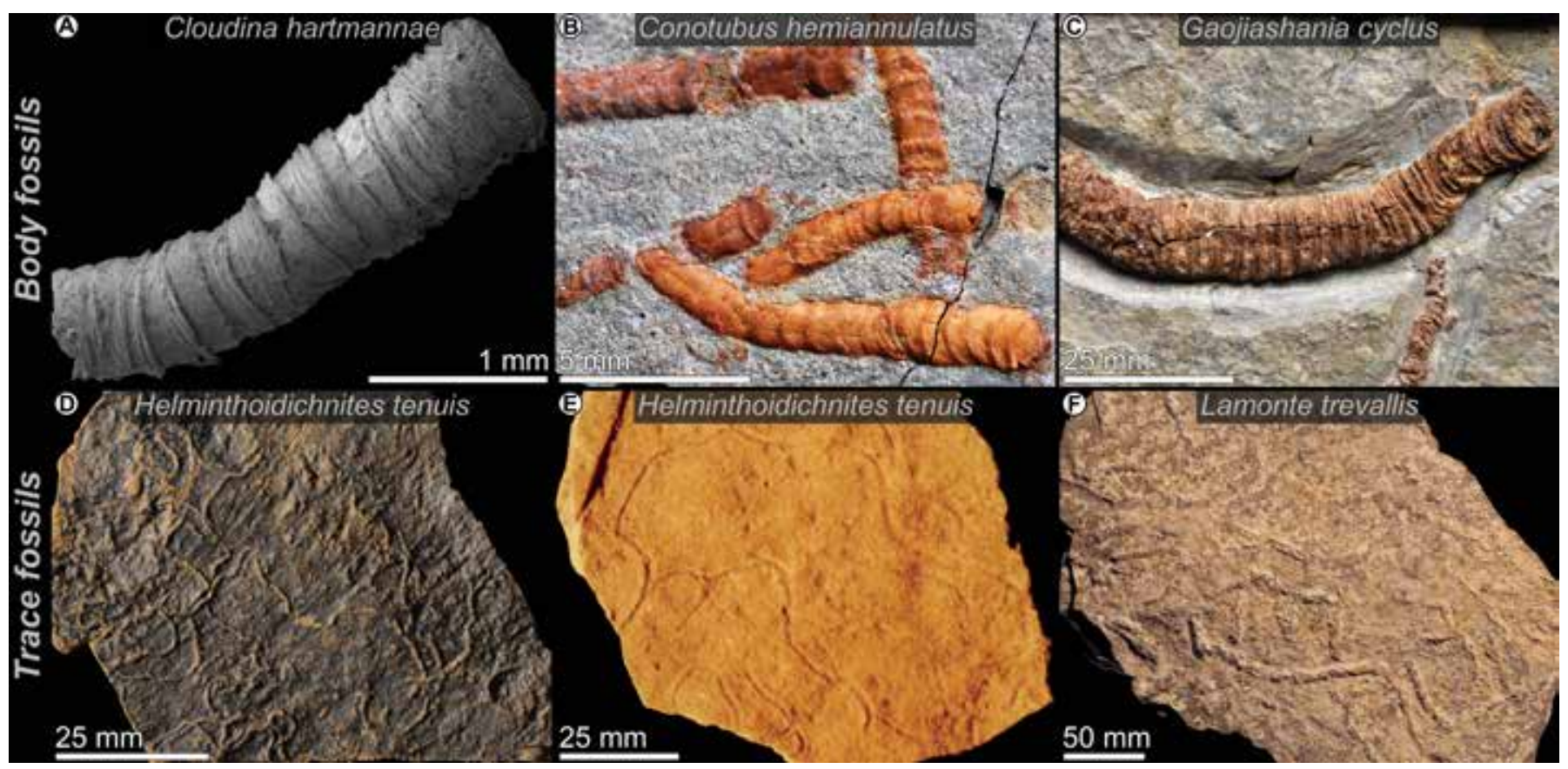

Figure 2. Representative wormworld body (A-C) and trace (D-F) fossils. (A-C) Tubular representatives from the Gaojiashan Lagerstätte, China; (D) surficial traces with micropustular elephant skin-like textures, Blueflower Formation, Canada (courtesy of C. Carbone); (E) surficial traces, Ediacara Member, Rawnsley Quartzite, South Australia (courtesy of L. Buatois); (F) complex undermat traces, Dengying Formation, China (courtesy of M. Meyer).

evolution in these sessile epibenthic ecosystems would have been driven by competition as reflected by niche partitioning and functional morphology in sessile communities (Bottjer and Ausich, 1986; Clapham and Narbonne, 2002).

\section{Benthos Modification}

Set against this competitive landscape, the first motile members of the second trophic tier ( $1^{\circ}$ consumers) began to exploit widespread microbial mats, sedimentary organic carbon, and possibly the decaying material of fallen Ediacarans (Budd and Jensen, 2015). Metazoan trace fossils from the last 25 m.y. of the Ediacaran period (ca. 565-541 Ma): (1) display behavioral evolution of the second trophic tier (Carbone and Narbonne, 2014; Chen et al., 2013; Meyer et al., 2014); (2) signify the development of sensory-muscular activity (Gehling et al., 2014; Jensen et al., 2005); (3) provide tangible evidence for both grazing and deposit feeding (Carbone and Narbonne, 2014); and (4) confirm a burgeoning and sophisticated motile component to benthic ecosystems, marking an important expansion of ecosystem engineering behaviors. Even with increasing species richness and ecosystem complexity through early Ediacaran assemblages (Shen et al., 2008; Xiao and Laflamme, 2009), the diversity of nascent bioturbating behaviors was restricted, possibly by benthic oxygen levels (Fike et al., 2006; Sperling et al., 2015) or by sharp sediment redox gradients maintained by the, at the time, still pervasive microbial blanketing of the shallow seafloor (Hagadorn and Bottjer, 1999). The complexity of traces in the ichnofossil record grew (Carbone and Narbonne, 2014), however, perhaps foreshadowing the coming revolution in the abiotic and biotic structure of the benthos (Bottjer et al., 2000). The redistribution of nutrients between the water column and the substrate in the latest Ediacaran, a significant consequence of bioturbation, could have resulted from many different shifts in biotic interactions. Notably, the expansion of the pelagic realm to accommodate larger mesozooplankton (Butterfield, 2009) would favor filter-feeding strategies over the passive diffusion of organics in osmotrophy. Furthermore, the innovation of metazoans with one-way guts (i.e., bilaterians) would have packaged nutrients in the form of fecal pellets, thus efficiently transporting nutrients from the water column to the substrate (Sperling et al., 2011) and benefiting detritivores at the cost of those reliant on dissolved nutrients. Nonetheless, there remains a delay between the emergence of surficial grazing behaviors and significant sediment mixing from vertical bioturbation (Tarhan et al., 2015). With an ostensibly limitless food source of microbial substrates (which persist into the Cambrian; Buatois et al., 2014) and the lack of macroscopic predation, there may not have been sufficient ecological stressors to drive metazoans into less hospitable or more physiologically challenging infaunal life modes. Nonetheless, the introduction of infaunalization and increasing intricacy of horizontal burrow networks at the Ediacaran-Cambrian transition (Hagadorn and Bottjer, 1999; Jensen, 2003) signaled a keystone development in ecosystem engineering, and began to propagate a shift-albeit protracted (Tarhan et al., 2015) —in the physical and chemical properties of the substrate.

\section{Ecological Antagonism}

The first occurrence of metazoan predation appears in the terminal Ediacaran (ca. 550-541 Ma), in concert with several other firsts, including metazoan biomineralization and the occupation of biohermal ecological niches (Cai et al., 2014; Penny et al., 2014; Wood and Curtis, 2015). The earliest mineralizing taxa appear in several contemporaneous units, such as the Nama Group, Namibia (Grotzinger et al., 2000); the Ara Group, Oman 
(Amthor et al., 2003); the Gaojiashan Lagerstätte, China (Cai et al., 2010; Cortijo et al., 2015a); Estena River, Spain (Cortijo et al., 2010; Cortijo et al., 2015b); and elsewhere (Hagadorn and Waggoner, 2000; Hofmann and Mountjoy, 2001; Zhuravlev et al., 2012). The best known from this group is the terminal Ediacaran index fossil and one of the first biomineralizers, Cloudina (Fig. 2A). The cloudinids and similar taxa (Figs. 2B and $2 \mathrm{C}$ ) remain phylogenetically enigmatic because of a lack of preserved soft-tissues (Schiffbauer et al., 2014); although, based on tube morphologies and growth patterns, these organisms have drawn comparisons with modern worms or anthozoan corals (Cai et al., 2014; Hua et al., 2005; Penny et al., 2014). While the presence of worm-like animals was previously established from the ichnofossil record, the cloudinids and similar taxa provide the first vermiform body fossils. Perhaps more importantly, the addition of $2^{\circ}$ consumers of the third trophic tier is marked by site-/taxon-specific and size-selective predatory drillholes in the biocalcified tubes of Cloudina (Bengtson and Yue, 1992; Hua et al., 2003). This novel feeding strategy would have presented a severe ecological pressure; indeed, $20 \%$ of individuals in some populations were drilled by predators (Hua et al., 2003). In addition to the added trophic level, the presence of these latest Ediacaran drillholes signifies three major evolutionary themes: (1) prey selectivity indicates the neural sophistication of the predator; (2) failed attempts (incomplete drillholes) demonstrate that mineralized exoskeletons impeded predators; and (3) predation pressure may have played a significant role in the proliferation of mineralized skeletons. With such a sophisticated predatory mechanism recorded in the tubes of Cloudina, it is likely that the origin of predation preceded this first occurrence. Given the similarities between drillholes in Cloudina and modern shelly prey, the organism responsible for Ediacaran drillholes was mechanically, if not phylogenetically, comparable to Phanerozoic drilling gastropods using a radulalike structure to rasp the prey skeleton. With Kimberella interpreted as a radula-bearing stem-group mollusk (Gehling et al., 2014), comparable physiological machinery for drilling predation may have already been in place $\sim 10$ m.y. before the first drillholes appear in the fossil record. However, from this fossil first occurrence and with improved preservation as a consequence of taphonomically robust biominerals, the record of macropredation is observed to increase in both frequency and predator/prey diversity well into the Phanerozoic (Huntley and Kowalewski, 2007).

\section{THE IMPORTANCE OF THE WORMWORLD}

While local facies and environmental controls have been shown to be of importance to understanding and appreciating the ecological contexts of classic Ediacaran communities (Gehling and Droser, 2013), currently available diversity data imply that the terminal Ediacaran is characterized by a considerably reduced Ediacara biota (Boag et al., 2016; Darroch et al., 2015; Shen et al., 2008; Xiao and Laflamme, 2009). Concurrently, eumetazoan vermiform body fossils and bilaterian trace fossils show an increase in diversity (Cai et al., 2014; Cai et al., 2011; Carbone and Narbonne, 2014; Wood and Curtis, 2015), offering glimpses into more modern ecosystem dynamics. The coupling of these records - the expansion of the wormworld fauna and diversity loss of classic Ediacarans (Laflamme et al., 2013; Xiao and
Laflamme, 2009) — suggests that vermiform metazoans may have played a role in displacing preexisting biotic components in the terminal Ediacaran marine ecosystems (Darroch et al., 2015; Darroch et al., 2016). However, much work remains to (1) establish what (if any) biotic interactions occurred between these two broad groups; and (2) determine how many Ediacaran morphoclades actually represent metazoan lineages, such that further discussion does not become mired in artificial and polyphyletic groupings (MacGabhann, 2014).

Contrary to the influence of competition in shaping Ediacaran communities, vermiform organisms witnessed an expansion in ecological strategies through the onset of three new life modes: (1) macropredation (Bengtson and Yue, 1992; Hua et al., 2003); (2) reef-building (Penny et al., 2014); and (3) motile grazing (Carbone and Narbonne, 2014). While it can be difficult to quantify competition in fossil communities, evidence for niche partitioning can be indicated by over-dispersion of body size (e.g., Huntley et al., 2008) and spatial arrangement (Clapham and Narbonne, 2002; Ghisalberti et al., 2014). In a sessile epibenthic ecosystem relatively free of predation and with few motile organisms, the availability of space and nutrients on and above the matground must have been limiting factors shaping community structure. In contrast, nutrient acquisition was presumably non-limiting for those few mobile organisms feeding on the microbial substrate (Tarhan et al., 2015), at least early in the development of motility and herbivory. Thus, it is likely that the evolutionary importance of competition for resources was not equal across environments and trophic tiers, and that factors such as predation and disturbance were more influential in shaping wormworld communities. Escalation, organisms responding evolutionarily to their enemies (Vermeij, 1987), places an evolutionary premium on predators rather than competitors. Consequently, counter to the largely sessile guilds of the Ediacaran, the evolution of motility and bioturbation, grazing by $1^{\circ}$ consumers, and predation by $2^{\circ}$ consumers, marks the most significant difference between earlier Ediacaran and Cambrian ecosystems (Butterfield, 2007). The wormworld fauna thus captures an explicit tipping point where predation and disturbance became dominant ecological factors.

We suggest that the wormworld fauna and the ecological complexities that they ushered in led to the displacement and eventual biotic replacement (Darroch et al., 2015) of the classic Ediacara-type communities. These vermiform organisms were equipped with innovative adaptations of active feeding modes and sediment restructuring capabilities, biomineralized armament against predators, generalist and opportunist adaptability to varying substrates (Cai et al., 2014), sexual and asexual reproduction for enhanced dispersal (Cortijo et al., 2015a), resilience to environmental disturbance (Cai et al., 2010), and presumably high fecundity and rapid achievement of sexual maturity. The wormworld organisms were likely more adept at attaining ecological success over the comparatively ineffectual occupation of niches by the classic Ediacara biota. Indeed, while classic Ediacarans show an apparent decline approaching the Ediacaran -Cambrian transition (Darroch et al., 2015), several reports indicate that at least some terminal Ediacaran tubicolous organisms (including Cambrotubulus, Platysolenites, Cloudina, and Sinotubulites) may traverse this boundary (e.g., Kontorovich et al., 2008; McMenamin, 1985; Rogov et al., 2015; Yochelson and 
Stump, 1977). In addition, the advent of predation added selective pressure to drive infaunalization (Dzik, 2007), expanding bioturbation vertically, reducing the availability of matground substrate upon which many Ediacara organisms grew, and advancing the ecosystem engineering feedback. The gregarious habit of some vermiform taxa may have additionally served as an antipredatory strategy and propagated ecosystem engineering via sediment baffling. It is important to note that the suggested mass extinction of the Ediacara biota in the context of our wormworld model is an ecologically driven event rather than an environmentally driven cataclysm akin to more recent (Phanerozoic) mass extinctions, and thus may have been comparatively protracted-as evidenced by Ediacara holdovers in the early Cambrian (Conway Morris, 1993; Hagadorn et al., 2000; Jensen et al., 1998). Nonetheless, whereas the static synecology and comparatively passive feeding modes of the classic Ediacarans had once emplaced a boundary on evolutionary possibility, the successful expansion of innovative traits of herbivory and carnivory, and their causal ties to infaunalization, reef-building, and biomineralization, permitted a new scaling of this bounding "right wall" (sensu Knoll and Bambach, 2000) as realized by the organisms of the wormworld fauna. Over time, the evolutionary breakthroughs conveyed by these neoteric organisms, including novel strategies, behaviors, and physiologies, increased the heterogeneity of benthic ecosystems, allowed for enhanced exploitation of resources, and established insurmountable increases in ecospace that ultimately signaled the curtain call for the Ediacara-type guilds.

\section{THE SEARCH FOR A TRIGGER}

The stark pattern of the Cambrian Explosion has steered many to identify a "trigger" (see reviews by Conway Morris, 2000; Erwin et al., 2011; Marshall, 2006; Xiao, 2014; Zhang et al., 2014). Previously proposed triggers can be categorized into three broad types (Erwin, 2015b): genetic, ecological, and environmental. For instance, a few examples include [genetic] the origin of the genetic toolkit for animal body plans; [ecological] bioturbation, predation, roughening of fitness landscapes, and adaptive radiation following an end-Ediacaran extinction; and [environmental] the Snowball Earth glaciations, increasing ocean oxygenation, and other dramatic seawater chemistry changes. While this is not the appropriate forum for an exhaustive discussion of triggers, we will briefly review three recent but distinct iterations of trigger hypotheses, centered on changing ocean chemistry, ties between oxygenation and carnivory, and nutritional incentive.

\section{The Great Unconformity}

Emphasizing the role of global environmental change, Peters and Gaines (2012) suggest that the Sauk transgression over the Great Unconformity flooded the continents and delivered excess ions to the ocean, necessitating a physiological response to intracellular calcium toxicity in the form of metazoan biomineralization. This evolutionary milestone, in conjunction with the expansion of shallow marine environments, promoted the explosive radiation of marine animals. The dominance of non-biomineralizing taxa in Burgess Shale-type biotas (Chen and Zhou, 1997; Conway Morris, 1986), however, implies that the Cambrian Explosion would have occurred with or without biomineralization (Butterfield, 2003). The temporal linkage of metazoan biomineralization and diversification begs the question as to whether they can be explained by the same trigger or are instead compounded causes and consequences of the immediately preceding and supervening events. Comparably, the initiation of the Mesozoic plankton radiation and contemporaneous expansion in planktic biomineralization (Knoll, 2003) proceeded without the presence of a global unconformity, echoing a disconnect between the oceanic influx of ions and evolutionary radiation.

\section{The Hypoxia Hypothesis}

Exploring the relationship between oxygen minimum zones and polychaete worm-feeding ecology in modern oceans as an analogue for terminal Ediacaran benthic communities, Sperling et al. (2013) propose an eco-environmental trigger. Their work emphasizes a series of requirements. First, an increase from suboxia to hypoxia (and stabilization of minimum oxygen content) removed a key limiting factor upon animal body size and permitted the establishment of more oxygen-demanding motile life modes. This resulted in increasing trophic complexity from expanding diversity and abundance of carnivorous taxa-and ultimately drove the evolutionary arms race resulting in the Cambrian Explosion.

\section{The Savannah Hypothesis}

While the former two hypotheses note the importance of predation and antipredatory (as presumed from the importance of biomineralization) strategies, the Savannah hypothesis of Budd and Jensen (2015) posits that the diversification of metazoan tracemakers was driven by resource heterogeneity from patches of post-burial Ediacara biota. Shallow burrowing behavior was the key evolutionary innovation that allowed exploitation of this resource. In conjunction with environmental heterogeneity and patch dynamics, such burrowing would have spurred the radiation of the bilateria-previously also tied to the advent of hard parts (e.g., Bengtson, 2004).

While there are broad similarities between the Savannah model and our proposed wormworld model, there are some key differences, which offer two testable hypotheses: (1) the majority of classic Ediacara-type organisms are interpreted by Budd and Jensen (2015) as stem metazoans and, thus, there would have been no biotic crisis among classic Ediacarans prior to the Cambrian (contra Laflamme et al., 2013); and (2) there should be clear positive spatial and temporal associations between Ediacara biota and trace fossils supporting the proposition that early bilaterians exploited decaying Ediacarans as a food source. Regarding the first prediction, on local-, regional-, and global-scales, latest Ediacaran fossil communities have been shown to be depauperate with respect to many iconic and readily preserved forms (Boag et al., 2016; Darroch et al., 2015; Xiao and Laflamme, 2009), supporting an extinction/biotic replacement scenario. With respect to the second prediction, available data suggest that direct associations between Ediacara-type organisms and bilaterian trace fossils are rare. Metazoan traces occur most frequently as isolated monospecific assemblages lacking Ediacara biota, suggestive of niche partitioning (Darroch et al., 2016). In China, vermiform trace fossils are found in the same stratigraphic sections as Ediacara biota, but only sometimes on the same beds, suggesting that their co-occurrence within communities was limited or that the classic Ediacara-type forms were relatively 
intolerant to bioturbation (Chen et al., 2014b). This may indicate that direct interactions between Ediacara organisms and motile vermiform bilaterians became common only when forced by the diversification of motile animals and expansion into new ecospace. Possibly capturing a snapshot of this changeover, the Wood Canyon Formation in the southwestern Great Basin of the United States preserves traces, a diverse tubicolous fauna, and classic Ediacarans in the same stratigraphic section (Hagadorn and Waggoner, 2000).

\section{SUMMARY - A SERIES OF SWITCHES?}

These three trigger hypotheses, among many others, illustrate the complexity of the Cambrian Explosion and the many factors that must be considered in its explanation-exemplifying why the identification of a lone trigger has been a thorny process.

Revisiting the three categories of triggers, the genetic toolkit for animal body plans is a requirement for the Cambrian Explosion, but its likely Cryogenian origin demonstrates that it was not an immediate trigger (Erwin, 2015a; Tweedt and Erwin, 2015). Purely environmental triggers correlate with the timing of the Explosion but cannot explain the evolutionary pattern, which is outwardly better explained by ecological triggers that create novel evolutionary opportunity (Butterfield, 2009; Sperling et al., 2013). With regard to the discussed hypotheses, it is important to note their overlap. Both the Great Unconformity and Hypoxia hypotheses involve predatory and antipredatory strategies, and both the Hypoxia and the Savannah hypotheses emphasize the role of vermiform organisms (or more broadly, bilaterians) in increasing predation, burrowing, and scavenging behaviors (with implications for neurological development; Budd and Jackson, 2016). The wormworld model underscores the role of the terminal Ediacaran vermiform fauna in significantly expanding the second trophic tier, intensifying ecosystem engineering behaviors, and establishing antipredatory mechanisms. In conjunction, these developments commenced a suite of antagonistic coevolutionary feedbacks between $1^{\circ}$ and $2^{\circ}$ consumers (i.e., the Red Queen hypothesis; Van Valen, 1973) amid the emerging Phanerozoicstyle ecological landscape, ultimately setting the stage for the Cambrian Explosion.

In sum, the Cambrian Explosion appears to be but a part of an extended series of molecular, ecological, and environmental revolutions spanning the late Neoproterozoic to early Paleozoic. Therefore, the search for a lone trigger, by nature, does not account for this complexity; instead, integrated constructs accounting for taxonomic, morphological, and ecological expansion facilitated by environmental changes and genetic toolkit exaptations should provide more inclusive explanations for the Cambrian Explosion. As such, we view the events of this interval as a series of switches, wherein each switch served to fundamentally alter and increase the complexity and functionality of ecosystems. We view the step-wise building of the Eltonian pyramid, in large part owing to the ecological and evolutionary novelties conveyed by the rise of the wormworld fauna, as prime examples of these switches - but only a part of a series of interconnected switches. These other requisite steps must have included the genetic toolkits for bilaterianism, the linkage of the pelagic and benthic ecosystems, the increase of oxygen to support animal metabolisms, and the creation of new habitats through both biotic processes and those related to contemporaneous supercontinent breakup - which collectively enabled, but did not guarantee, the rise of animals yet to come.

\section{ACKNOWLEDGMENTS}

For D.L.S. We thank G. Dickens and three anonymous reviewers for constructive feedback, and we are grateful for the conversations with numerous colleagues that helped shape our thoughts on this topic.

\section{REFERENCES CITED}

Amthor, J.E., Grotzinger, J.P., Schröder, S., Bowring, S.A., Ramezani, J., Martin, M.W., and Matter, A., 2003, Extinction of Cloudina and Namacalathus at the Precambrian-Cambrian boundary in Oman: Geology, v. 31, no. 5, p. 431-434, doi: 10.1130/0091-7613(2003)031<0431:EOCANA>2.0.CO;2.

Antcliffe, J.B., Callow, R.H.T., and Brasier, M.D., 2014, Giving the early fossil record of sponges a squeeze: Biological Reviews of the Cambridge Philosophical Society, v. 89, p. 972-1004, doi: 10.1111/brv.12090.

Bengtson, S., 2004, Early skeletal fossils: Paleontological Society Papers, v. 10, p. 67.

Bengtson, S., and Yue, Z., 1992, Predatorial borings in late Precambrian mineralized exoskeletons: Science, v. 257, 5068, p. 367-369, doi: 10.1126/ science.257.5068.367.

Boag, T.H., Darroch, S.A.F., and Laflamme, M., 2016, Ediacaran distributions in space and time: Testing assemblage concepts of earliest macroscopic body fossils: Paleobiology, doi: 10.1017/pab.2016.20.

Bottjer, D.J., and Ausich, W.I., 1986, Phanerozoic development of tiering in soft substrata suspension-feeding communities: Paleobiology, v. 12, no. 4, p. 400-420, doi: 10.1017/S0094837300003134.

Bottjer, D.J., Hagadorn, J.W., and Dornbos, S.Q., 2000, The Cambrian substrate revolution: GSA Today, v. 10, no. 9, p. 1-7.

Briggs, D.E., Fortey, R.A., and Wills, M.A., 1992, Morphological disparity in the Cambrian: Science, v. 256, 5064, p. 1670-1673, doi: 10.1126/ science. 256.5064 .1670 .

Buatois, L.A., Narbonne, G.M., Mángano, M.G., Carmona, N.B., and Myrow, P., 2014, Ediacaran matground ecology persisted into the earliest Cambrian: Nature Communications, v. 5, 3544, doi: 10.1038/ ncomms 4544 .

Budd, G.E., and Jackson, I.S.C., 2016, Ecological innovations in the Cambrian and the origins of the crown group phyla: Philosophical Transactions of the Royal Society of London, Series B, Biological Sciences, v. 371, doi: 10.1098/rstb.2015.0287.

Budd, G.E., and Jensen, S., 2015, The origin of the animals and a 'Savannah' hypothesis for early bilaterian evolution: Biological Reviews of the Cambridge Philosophical Society, doi: 10.1111/brv.12239.

Butterfield, N.J., 1997, Plankton ecology and the Proterozoic-Phanerozoic transition: Paleobiology, v. 23, p. 247-262, doi: 10.1017/ S009483730001681X.

Butterfield, N.J., 2003, Exceptional fossil preservation and the Cambrian explosion: Integrative and Comparative Biology, v. 43, p. 166-177, doi: 10.1093/icb/43.1.166.

Butterfield, N.J., 2007, Macroevolution and macroecology through deep time: Palaeontology, v. 50, p. 41-55, doi: 10.1111/j.1475-4983.2006.00613.x.

Butterfield, N.J., 2009, Oxygen, animals and oceanic ventilation: An alternative view: Geobiology, v. 7, p. 1-7, doi: 10.1111/j.1472-4669.2009.00188.x.

Cai, Y., Hua, H., Xiao, S., Schiffbauer, J.D., and Li, P., 2010, Biostratinomy of the late Ediacaran pyritized Gaojiashan Lagerstätte from southern Shaanxi, South China: Importance of event deposits: Palaios, v. 25, p. 487-506, doi: 10.2110/palo.2009.p09-133r.

Cai, Y., Schiffbauer, J.D., Hua, H., and Xiao, S., 2011, Morphology and paleoecology of the late Ediacaran tubular fossil Conotubus hemiannulatus from the Gaojiashan Lagerstätte of southern Shaanxi Province, South China: Precambrian Research, v. 191, p. 46-57, doi: 10.1016/j .precamres.2011.09.002.

Cai, Y., Hua, H., Schiffbauer, J.D., Sun, B., and Yuan, X., 2014, Tube growth patterns and microbial mat-related lifestyles in the Ediacaran fossil Cloudina, Gaojiashan Lagerstätte, South China: Gondwana Research, v. 25, p. 1008-1018, doi: 10.1016/j.gr.2012.12.027. 
Carbone, C., and Narbonne, G.M., 2014, When life got smart: The evolution of behavioral complexity through the Ediacaran and Early Cambrian of NW Canada: Journal of Paleontology, v. 88, p. 309-330, doi: 10.1666/13-066.

Chen, J., and Zhou, G., 1997, Biology of the Chengjiang fauna: Bulletin of the National Museum of Natural Science (Taichung, China), v. 10, p. 11-105.

Chen, Z., Zhou, C., Meyer, M., Xiang, K., Schiffbauer, J.D., Yuan, X., and Xiao, S., 2013, Trace fossil evidence for Ediacaran bilaterian animals with complex behaviors: Precambrian Research, v. 224, p. 690-701, doi: 10.1016/j.precamres.2012.11.004.

Chen, L., Xiao, S., Pang, K., Zhou, C., and Yuan, X., 2014a, Cell differentiation and germ-soma separation in Ediacaran animal embryo-like fossils: Nature, v. 516, p. 238-241, doi: 10.1038/nature13766.

Chen, Z., Zhou, C., Xiao, S., Wang, W., Guan, C., Hua, H., and Yuan, X., 2014b, New Ediacara fossils preserved in marine limestone and their ecological implications: Nature Scientific Reports, v. 4, 4180, doi: 10.1038/srep04180.

Clapham, M.E., and Narbonne, G.M., 2002, Ediacaran epifaunal tiering: Geology, v. 30, no. 7, p. 627-630, doi: 10.1130/0091-7613(2002)030 $<0627$ :EET>2.0.CO;2.

Conway Morris, S., 1986, The community structure of the middle Cambrian Phyllopod Bed (Burgess Shale): Palaeontology, v. 29, p. 423-467.

Conway Morris, S., 1993, Ediacaran-like fossils in Cambrian Burgess Shale-type faunas of North America: Palaeontology, v. 36, p. 593-635.

Conway Morris, S., 2000, The Cambrian “explosion”: Slow-fuse or megatonnage?: Proceedings of the National Academy of Sciences of the United States of America, v. 97, p. 4426-4429, doi: 10.1073/pnas.97.9.4426.

Cortijo, I., Mus, M.M., Jensen, S., and Palacios, T., 2010, A new species of Cloudina from the terminal Ediacaran of Spain: Precambrian Research, v. 176, p. 1-10, doi: 10.1016/j.precamres.2009.10.010.

Cortijo, I., Cai, Y., Hua, H., Schiffbauer, J.D., and Xiao, S., 2015a, Life history and autecology of an Ediacaran index fossil: Development and dispersal of Cloudina: Gondwana Research, v. 28, p. 419-424, doi: 10.1016/j .gr.2014.05.001.

Cortijo, I., Mus, M.M., Jensen, S., and Palacios, T., 2015b, Late Ediacaran skeletal body fossil assemblage from the Navalpino anticline, central Spain: Precambrian Research, v. 267, p. 186-195, doi: 10.1016/j .precamres.2015.06.013.

Darroch, S.A.F., Sperling, E.A., Boag, T.H., Racicot, R.A., Mason, S.J., Morgan, A.S., Tweedt, S., Myrow, P., Johnston, D.T., and Erwin, D.H., 2015, Biotic replacement and mass extinction of the Ediacara biota: Proceedings of the Royal Society B (Biological Sciences), v. 282, 1814, doi: 10.1098/ rspb.2015.1003.

Darroch, S.A.F., Boag, T.H., Racicot, R.A., Tweedt, S., Mason, S.J., Erwin, D.H., and Laflamme, M., 2016, A mixed Ediacaran-metazoan fossil assemblage from the Zaris Sub-basin, Namibia: Palaeogeography, Palaeoclimatology, Palaeoecology, doi: 10.1016/j.palaeo.2016.07.003.

dos Reis, M., Thawornwattana, Y., Angelis, K., Telford, M.J., Donoghue, P.C., and Yang, Z., 2015, Uncertainty in the timing of origin of animals and the limits of precision in molecular timescales: Current Biology, v. 25, no. 22, p. 2939-2950, doi: 10.1016/j.cub.2015.09.066.

Dzik, J., 2007, The Verdun Syndrome: Simultaneous origin of protective armour and infaunal shelters at the Precambrian-Cambrian transition: Geological Society of London Special Publication 286, p. 405-414, doi: 10.1144/SP286.30.

Erwin, D.H., 2007, Disparity: Morphological pattern and developmental context: Palaeontology, v. 50, no. 1, p. 57-73, doi: 10.1111/j.1475-4983.2006.00614.x.

Erwin, D.H., 2015a, Novelty and innovation in the history of life: Current Biology, v. 25, no. 19, p. R930-R940, doi: 10.1016/j.cub.2015.08.019.

Erwin, D.H., 2015b, Was the Ediacaran-Cambrian radiation a unique evolutionary event?: Paleobiology, v. 41, no. 1, p. 1-15, doi: 10.1017/ pab.2014.2.

Erwin, D.H., Laflamme, M., Tweedt, S.M., Sperling, E.A., Pisani, D., and Peterson, K.E., 2011, The Cambrian conundrum: Early divergence and later ecological success in the early history of animals: Science, v. 334, p. 1091-1097, doi: 10.1126/science.1206375.

Fike, D.A., Grotzinger, J.P., Pratt, L.M., and Summons, R.E., 2006, Oxidation of the Ediacaran ocean: Nature, v. 444, p. 744-747, doi: 10.1038/ nature05345.
Gehling, J.G., and Droser, M.L., 2013, How well do fossil assemblages of the Ediacara Biota tell time?: Geology, v. 41, no. 4, p. 447-450, doi: 10.1130/ G33881.1.

Gehling, J.G., Runnegar, B.N., and Droser, M.L., 2014, Scratch traces of large Ediacara bilaterian animals: Journal of Paleontology, v. 88, p. 284-298, doi: 10.1666/13-054

Ghisalberti, M., Gold, D.A., Laflamme, M., Clapham, M.E., Narbonne, G.M., Summons, R.E., Johnston, D.T., and Jacobs, D.K., 2014, Canopy flow analysis reveals the advantage of size in the oldest communities of multicellular eukaryotes: Current Biology, v. 24, p. 305-309, doi: 10.1016/j.cub.2013.12.017.

Grotzinger, J.P., Watters, W.A., and Knoll, A.H., 2000, Calcified metazoans in thrombolite-stromatolite reefs of the terminal Proterozoic Nama Group, Namibia: Paleobiology, v. 26, no. 3, p. 334-359, doi: 10.1666/0094-8373(2000)026<0334:CMITSR >2.0.CO;2.

Hagadorn, J.W., and Bottjer, D.J., 1999, Restriction of a Late Neoproterozoic biotope: Suspect-microbial structures and trace fossils at the VendianCambrian transition: Palaios, v. 14, p. 73-85, doi: 10.2307/3515362.

Hagadorn, J.W., and Waggoner, B.M., 2000, Ediacaran fossils from the southwestern Great Basin, United States: Journal of Paleontology, v. 74, no. 2, p. 349-359, doi: 10.1666/0022-3360(2000)074<0349:EFFTSG $>2.0 . \mathrm{CO} ; 2$.

Hagadorn, J.W., Fedo, C.M., and Waggoner, B.M., 2000, Early Cambrian Ediacaran-type fossils from California: Journal of Paleontology, v. 74, no. 4, p. 731-740, doi: 10.1666/0022-3360(2000)074<0731:ECETFF $>2.0 . \mathrm{CO} ; 2$.

Hofmann, H.J., and Mountjoy, E.W., 2001, Namacalathus-Cloudina assemblage in Neoproterozoic Miette Group (Byng Formation), British Columbia: Canada's oldest shelly fossils: Geology, v. 29, no. 12, p. 1091-1094, doi: 10.1130/0091-7613(2001)029<1091:NCAINM>2.0.CO;2.

Hua, H., Chen, Z., Yuan, X., Zhang, L., and Xiao, S., 2005, Skeletogenesis and asexual reproduction in the earliest biomineralizing animal Cloudina: Geology, v. 33, no. 4, p. 277-280, doi: 10.1130/G21198.1.

Hua, H., Pratt, B.R., and Zhang, L., 2003, Borings in Cloudina shells: Complex predator-prey dynamics in the terminal Neoproterozoic: Palaios, v. 18, p. 454-459, doi: 10.1669/0883-1351(2003)018<0454:BICSCP>2.0.CO;2.

Huntley, J.W., and Kowalewski, M., 2007, Strong coupling of predation intensity and diversity in the Phanerozoic fossil record: Proceedings of the National Academy of Sciences of the United States of America, v. 104, p. 15,006-15,010, doi: 10.1073/pnas.0704960104.

Huntley, J.W., Yanes, Y., Kowalewski, M., Castillo, C., Delgado-Huertas, A., Ibanez, M., Alonso, M.R., Ortiz, J.E., and de Torres, T., 2008, Testing limiting similarity in Quaternary terrestrial gastropods: Paleobiology, v. 34, p. 378-388, doi: 10.1666/07058.1.

Jensen, S., 2003, The Proterozoic and earliest Cambrian trace fossil record: Patterns, problems and perspectives: Integrative and Comparative Biology, v. 43, p. 219-228, doi: 10.1093/icb/43.1.219.

Jensen, S., Gehling, J.G., and Droser, M.L., 1998, Ediacara-type fossils in Cambrian sediments: Nature, v. 393, p. 567-569, doi: 10.1038/31215.

Jensen, S., Droser, M.L., and Gehling, J.G., 2005, Trace fossil preservation and the early evolution of animals: Palaeogeography, Palaeoclimatology, Palaeoecology, v. 220, p. 19-29, doi: 10.1016/j.palaeo.2003.09.035.

Keto, L.S., and Jacobson, S.B., 1988, Nd isotopic variations of Phanerozoic palaeoceans: Earth and Planetary Science Letters, v. 90, p. 395-410, doi: 10.1016/0012-821X(88)90138-0.

Knoll, A.H., 2003, Biomineralization and evolutionary history: Reviews in Mineralogy and Geochemistry, v. 54, p. 329-356, doi: 10.2113/0540329.

Knoll, A.H., and Bambach, R.K., 2000, Directionality in the history of life: Diffusion from the left wall or repeated scaling of the right? in Erwin, D.H., and Wing, S.L., eds., Deep Time: Paleobiology's Perspective: Lawrence, Kansas, The Paleontological Society and Allen Press, p. 1-14, doi: 10.1666/0094-8373(2000)26[1:DITHOL]2.0.CO;2.

Kontorovich, A.E., Varlamov, A.I., Grazhdankin, D.V., Karlova, G.A., Klets, A.G., Kontorovich, V.A., Saraev, S.V., Terleev, A.A., Belyaev, S.Y., Varaksina, I.V., Efimov, A.S., Kochnev, B.B., Nagovitsin, K.E., Postnikov, A.A., and Filippov, Y.F., 2008, A section of Vendian in the east of West Siberian Plate (based on data from the Borehole Vostok 3): Russian Geology and Geophysics, v. 49, p. 932-939. 
Laflamme, M., Xiao, S., and Kowalewski, M., 2009, Osmotrophy in modular Ediacara organisms: Proceedings of the National Academy of Sciences of the United States of America, v. 106, p. 14,438-14,443, doi: 10.1073/ pnas. 0904836106 .

Laflamme, M., Darroch, S.A.F., Tweedt, S.M., Peterson, K.J., and Erwin, D.H., 2013, The end of the Ediacara biota: Extinction, biotic replacement, or Cheshire Cat?: Gondwana Research, v. 23, p. 558-573, doi: 10.1016/j .gr.2012.11.004.

MacGabhann, B.A., 2014, There is no such thing as the 'Ediacara Biota': Geoscience Frontiers, v. 5, no. 1, p. 53-62, doi: 10.1016/j.gsf.2013.08.001.

Maloof, A.C., Porter, S.M., Moore, J.L., Dudás, F.Ö., Bowring, S.A., Higgins, J.A., Fike, D.A., and Eddy, M.P., 2010, The earliest Cambrian record of animals and ocean geochemical change: GSA Bulletin, v. 122, p. 17311774, doi: 10.1130/B30346.1.

Marshall, C.R., 2006, Explaining the Cambrian "explosion" of animals: Annual Review of Earth and Planetary Sciences, v. 34, p. 355-384, doi: 10.1146/ annurev.earth.33.031504.103001.

McMenamin, M.A.S., 1985, Basal Cambrian small shelly fossils from the La Cienega Formation, northwestern Sonora, Mexico: Journal of Paleontology, v. 59, no. 6, p. 1414-1425.

Meyer, M., Xiao, S., Gill, B.C., Schiffbauer, J.D., Chen, Z., Zhou, C., and Yuan, X., 2014, Interactions between Ediacaran animals and microbial mats: Insights from Lamonte trevalis, a new trace fossil from the Dengying Formation of South China: Palaeogeography, Palaeoclimatology, Palaeoecology, v. 396, p. 62-74, doi: 10.1016/j.palaeo.2013.12.026.

Narbonne, G.M., 2005, The Ediacara biota: Neoproterozoic origin of animals and their ecosystems: Annual Review of Earth and Planetary Sciences, v. 33, p. 421-442, doi: 10.1146/annurev.earth.33.092203.122519.

Penny, A., Wood, R., Curtis, A., Bowyer, F., Tostevin, R., and Hoffman, K.-H., 2014, Ediacaran metazoan reefs from the Nama Group, Namibia: Science, v. 344, 6191, p. 1504-1506, doi: 10.1126/science.1253393.

Peters, S.E., and Gaines, R.R., 2012, Formation of the 'Great Unconformity' as a trigger for the Cambrian explosion: Nature, v. 484, 7394, p. 363-366, doi: 10.1038/nature10969.

Peterson, K.J., Cotton, J.A., Gehling, J.G., and Pisani, D., 2008, The Ediacaran emergence of bilaterians: Congruence between the genetic and the geological fossil records: Philosophical Transactions of the Royal Society of London. Series B, Biological Sciences, v. 363, p. 1435-1443, doi: 10.1098/ rstb.2007.2233.

Rahman, I.A., Darroch, S.A.F., Racicot, R.A., and Laflamme, M., 2015, Suspension feeding in the enigmatic Ediacaran organism Tribrachidium demonstrates complexity of Neoproterozoic ecosystems: Science Advances, v. 1, e1500800, doi: 10.1126/sciadv.1500800.

Rogov, V.I., Karlova, G.A., Marusin, V.V., Kochnev, B.B., Nagovitsin, K.E., and Grazhdankin, D.V., 2015, Duration of the first biozone in the Siberian hypostratotype of the Vendian: Russian Geology and Geophysics, v. 56, no. 4 , p. $573-583$.

Saltzman, M., and Thomas, E., 2012, Carbon isotope stratigraphy, in Gradstein, F.M., Ogg, J.G., Schmitz, M., and Ogg, G., eds., The Geologic Time Scale, volume 1: Amsterdam, Elsevier, p. 207-232, doi: 10.1016/B978-0-44459425-9.00011-1.

Schiffbauer, J.D., Xiao, S., Cai, Y., Wallace, A.F., Hua, H., Hunter, J., Xu, H., Peng, Y., and Kaufman, A.J., 2014, A unifying model for NeoproterozoicPaleozoic exceptional fossil preservation through pyritization and carbonaceous compression: Nature Communications, v. 5, 5754, doi: 10.1038/ncomms6754.

Sepkoski, J.J., Jr., 1981, A factor analytic description of the Phanerozoic marine fossil record: Paleobiology, v. 7, no. 1, p. 36-53, doi: 10.1017/ S0094837300003778.
Shen, B., Dong, L., Xiao, S., and Kowalewski, M., 2008, The Avalon explosion: Evolution of Ediacara morphospace: Science, v. 319, p. 81-84, doi: 10.1126/science.1150279.

Sperling, E.A., and Vinther, J., 2010, A placozoan affinity for Dickinsonia and the late Precambrian evolution of metazoan feeding modes: Evolution \& Development, v. 12, p. 201-209, doi: 10.1111/j.1525-142X.2010.00404.x.

Sperling, E.A., Laflamme, M., and Peterson, K.J., 2011, Rangeomorphs, Thectardis (Porifera?) and dissolved organic carbon in the Ediacaran ocean: Geobiology, v. 9, p. 24-33, doi: 10.1111/j.1472-4669.2010.00259.x.

Sperling, E.A., Frieder, C.A., Raman, A.V., Girguis, P.R., Levin, L.A., and Knoll, A.H., 2013, Oxygen, ecology, and the Cambrian radiation of animals: Proceedings of the National Academy of Sciences of the United States of America, v. 110, p. 13,446-13,451, doi: 10.1073/pnas.1312778110.

Sperling, E.A., Wolock, C.J., Morgan, A.S., Gill, B.C., Kunzmann, M., Halverson, G.P., Macdonald, F.A., Knoll, A.H., and Johnston, D.T., 2015, Statistical analysis of iron geochemical data suggests limited late Proterozoic oxygenation: Nature, v. 523, p. 451-454, doi: 10.1038/ nature14589.

Tarhan, L.G., Droser, M.L., Planavsky, N.J., and Johnston, D.T., 2015, Protracted development of bioturbation through the early Palaeozoic Era: Nature Geoscience, v. 8, p. 865-869, doi: 10.1038/ngeo2537.

Tweedt, S.M., and Erwin, D.H., 2015, Origin of metazoan developmental toolkits and their expression in the fossil record: Evolutionary Transitions to Multicellular Life: Berlin, Springer, p. 47-77.

Van Valen, L., 1973, A new evolutionary law: Evolutionary Theory, v. 1, p. 1-30.

Vermeij, G.J., 1987, Evolution and Escalation: An Ecological History of Life: Princeton, New Jersey, Princeton University Press, 527 p.

Wood, R., and Curtis, A., 2015, Extensive metazoan reefs from the Ediacaran Nama Group, Namibia: The rise of benthic suspension feeding: Geobiology, v. 13, p. 112-122.

Xiao, S., 2014, Oxygen and early animal evolution, in Farquhar, J., ed., Treatise on Geochemistry, Volume 6: Dordrecht, Elsevier, p. 231-250, doi: 10.1016/B978-0-08-095975-7.01310-3.

Xiao, S., and Laflamme, M., 2009, On the eve of animal radiation: Phylogeny, ecology and evolution of the Ediacara biota: Trends in Ecology \& Evolution, v. 24, p. 31-40, doi: 10.1016/j.tree.2008.07.015.

Yochelson, E.L., and Stump, E., 1977, Discovery of early Cambrian fossils at Taylor Nunatak, Antarctica: Journal of Paleontology, v. 51, no. 4, p. 872-875.

Yin, Z., Zhu, M., Davidson, E.H., Bottjer, D.J., Zhao, F., and Tafforeau, P., 2015, Sponge grade body fossil with cellular resolution dating $60 \mathrm{Myr}$ before the Cambrian: Proceedings of the National Academy of Sciences of the United States of America, v. 112, no. 12, E1453-E1460.

Yin, Z., Zhu, M., Bottjer, D.J., Zhao, F., and Tafforeau, P., 2016, Meroblastic cleavage identifies some Ediacaran Doushantuo (China) embryo-like fossils as metazoans: Geology, v. 44, doi: 10.1130/G38262.1.

Zhang, X., Shu, D., Han, J., Zhang, Z., Liu, J., and Fu, D., 2014, Triggers for the Cambrian explosion: Hypotheses and problems: Gondwana Research, v. 25, p. 896-909, doi: 10.1016/j.gr.2013.06.001.

Zhuravlev, A.Y., Liñán, E., Gámez Vintaned, J.A., Debrenne, F., and Fedorov, A.B., 2012, New finds of skeletal fossils in the terminal Neoproterozoic of the Siberian Platform and Spain: Acta Palaeontologica Polonica, v. 57, p. 205-224, doi: 10.4202/app.2010.0074.

Manuscript received 24 Sept. 2015; accepted 16 May 2016. 